\title{
THE ROLE OF THE NEWEST INTERACTIVE DISTANCE TECHNOLOGIES IN FORMATION OF FOREIGN LANGUAGE SOCIOCULTURAL COMPETENCE OF PART-TIME STUDENTS IN TECHNICAL UNIVERSITIES
}

\author{
Ya. S. Gryshchenko, I. A. Sydorenko \\ Kyiv, National Technical University of Ukraine \\ "Kyiv Polytechnic Institute" \\ Yanagri13@gmail.com, irysia.83@mail.ru
}

\begin{abstract}
The present article is devoted to the determination of the role of the newest interactive distance technologies in the formation of foreign language sociocultural competence of the part-time technical students. At the beginning of the article the quantitative indexes of time intended for the individual work in the form of tutorial via the Internet, classroom tutorial and on-line conferences are presented. The article introduces the detailed review of interactive methods of learning which can be applied during distant teacher-student cooperation at the intersession period. The analysis of means of teacher-student communication through the Internet is also carried out, in frames of which two kinds of communication (on-line and off-line) are considered. To the first category communication by means of the electronic correspondence, exchange of personal points of view at forums, blogging, communication via teacher's Web page (site) are referred. The latter includes correspondence with the help of ICQ, Quip, Skype and communication through the Webinar system, the notion of which is assiduously studied in our research. The practical part encompasses the results of the experiment conducted with the students of Welding faculty, Faculties of Physical Engineering and Chemical Technology on the platform of Mikogo on the topic "World Famous Inventors and Inventions". At the final part of the article we made the general conclusion that the Webinar is really an effective tool to form the foreign language sociocultural competence of part-time students in higher technical institutions. As the prospect of our further investigation the following is defined: carrying out the experiments with greater quantity of participants and more detailed revision of possibilities of Webinar platforms employment while foreign language learning.

Key words: foreign language sociocultural competence, distance learning, Webinar, interactive method, seminar.
\end{abstract}

Introduction. Question of the formation of social competence of students in foreign language learning draws researchers' attention. However, the issue has got a new development with the introduction of new information technologies into the educational process.

Aim and tasks. The purpose of this paper is to examine the role of new interactive distance technologies in the formation of foreign language sociocultural competence of part-time students of technical specialities. The tasks of the investigation are: to outline the main scientific approaches to the problem, to define the part of the time allocated to the different types of English language acquisition, to classify the interactive methods of teaching and types of teacher-student interaction via Internet, to conduct an experiment.

Background. Nowadays, our researchers consider this problem from two angles: from the point of view of philological specialties (S. Yu. Nikolaeva, T. I. Oleinyk, O. I. Selivanova, N. K. Skliarenko, I. H. Taranenko, etc.), and in terms 
of technical ones (V. N. Topalova, R. O. Hryshkova). It is precisely the second area that approximated to the purpose of our study. Despite the fact that the works of V. N. Topalova [4] and R. O. Hryshkova [1] are devoted to the problems of the formation of social competence of students in non-philological universities, they do not handle this problem in accordance with the peculiarities of foreign language teaching of part-time students, and this is the novelty of our study.

It should be noted that the beginning of general European integration of educational process is one of the reasons of increasing requirements to the level of English language learning curve of students in higher educational institutions. And, it is precisely the activization of technology transfer process between countries that suggests the focus on technical universities and institutes. Orientation of graduates for scientific researches and ever-increasing amount of information further the searching and adoption of such English language teaching techniques, which should develop the student's ability to mutually beneficial cooperation and exchange of experiences and ideas with foreign colleagues. In other words, such kind of orientation causes the use of interactive teaching techniques.

In accordance with the practical experience of foreign language teachers in technical educational institutions, the majority of students works for improving their communicative skills and tries to learn how to communicate fluently in English. But, as is generally known, the best possible study and digestion of new material takes place in classroom, during completing exercises, intended for the development of speech activity.

Preliminary study. Taking into consideration the fact that the number of hours devoted to classroom training with part-time students is the smallest part of the time allocated to the English language acquisition, the most favourable hours for activation of English language training technology on the extension departments of technical universities is the time allotted for independent students' work during the intercessional period. In the issue of preliminary research results, the quantity of English language tutorial hours conducting through the Internet should average about $45 \%$, the same quantity should be devoted to the tutorial classroom training, and $10 \%$ of tutorial hours should be intended for on-line conferences and seminars. Precisely these $10 \%$ of the time may be assigned to the formation of foreign language sociocultural competence of students via the Internet, but it is necessary to choose interactive means of distant communication.

The most common interactive methods in English teaching community are considered to be as follows: brainstorming, discussion of critical phenomenon, basket (language immersion), group discussion, language learning game, forum, imitation, modelling, seminar, method of projects [3, p. 25-54].

From the results of previous analysis and experimental practical application it is concluded that foresaid methods should be divided into two separate groups:

1) methods, which may be more useful for classroom trainings (brainstorming, discussion of critical phenomenon, basket (language immersion), group discussion);

2) methods, which can be used via the Internet (language learning game, forum, imitation, modelling, seminar, method of projects). 
Brainstorming is the most widely used method of the first group. This method is applicable in the situations when the teacher seeks for students' fluent English communication on a given problem-oriented topic, but, along with this, detailed discussion is not obligatory. These ideas are systematized and graded on a definite scale. The foresaid method provides a high activity of participants and develops their communicative skills. It gives the students of technical specialities an opportunity for self-actualization in foreign cultural society. It should be stressed, however, that the performing of such exercises requires face-to-face contact between teacher and students. And, this kind of "live dialogue" does not depend on the differences in technical layout of workplaces of the communicants and their computer skills that is still very difficult to implement in the process of virtual contact.

Method of the discussion of critical phenomenon is better to put into practice in a definite succession. At first the audience is reported on the situation, which is up for debate and detailed discussion. Then the students ask the teacher as many questions as possible in their aspiration to hear something new regarding the discussed phenomena to detail it and get additional information or even find any possible rational approaches to its solution. This interactive method aims to promote the progression of decision-making skills, problem solving techniques in unusual situations and the development of interpersonal relationships among one group of students [3, p. 38-45]. However, the method of the discussion of critical phenomenon is unproductive in distant communication by the same reasoning as for the previous one.

Basket technique or method of language immersion is the discussion of concrete problem or critical situation, and the students may already have their own answer templates. Such kind of discussion has sufficiently impressive effect on the development of cognitive thinking, helps students in forming of their own views on a particular issue and deepens knowledge on the issue under discussion. All that skills can be improved even if the students do not take direct active participation in the discussion. Being applied practically, this method can be organized both in group and in individual communication; the method has also proven to be ineffective via Internet.

Thus, despite the fact that the foresaid methods of interactive learning could theoretically be used in distant format, they require a high degree of concentration and quick reaction, which in terms of varying levels of students' training and technical layout of their workplaces complicates the process of communication and reduces the degree of exercises' effectiveness.

The methods of teaching foreign languages referring to the second group, as evidenced by the results of the preliminary study, are more effective in distant learning.

Listening skills and the consolidation of necessary vocabulary and terminology are developed by using the method of language learning game, which is accompanied by the processes of syntactic and grammar material review, and the increase of professional terminological vocabulary. In addition, the game promotes the skills of student's "live" spontaneous speaking. This method is a kind of variation task that allows repeating and consolidating the studied material in a form of real 
communication [3, p. 30-38]. The independent distant student's study can be organised with the method of language learning game. And, it is especially useful when the point of issue is part-time students.

Another kind of training is method of modelling. It can help technical part-time students to open their potential abilities, creative thinking and imaginativeness in English language learning. Students may choose their own roles, look for problem model for further solution and assume responsibilities for the right decision.

Imitations are called the imaginary situations when students are trying to imitate the surrounding reality. They are working individually without assistance or joining the group. Such imitative educational games favour the development of attention and skills of cognitive thinking; give the opportunity to learn how to find the only correct solution of the scientific problem they face.

Such notion as forum is known to be a method of collective discussion of a certain critical situation without limited time frames. The only precondition is that students should practice to focus and keep their attention, to participate actively and not be afraid to share their ideas publicly.

Seminar conduces to detailed mastering of theoretical material by students. It helps students to form oratorical skills, develops their ability to debate and advance arguments, encourages issuing and proving their own statements, prepares for the public address, teaches to have tolerant discussion.

It is supposed that project work demands not only individual but also creative approach to the teamwork. Students are requested to show all their intellectual potential to solve the problematic situation being modeled during the project cooperation. To implement this rather complicated methodology into pedagogical practice all participants of the project need to have appropriate linguistic preparation, sufficient knowledge of necessary lexical and grammatical material (correspondent with the subject of a lesson) and the opportunity to form their fluent speaking skills at the initial stage of studying [3, p. 65-71].

Problem of Research. The fact is that all referred methods of the second group may be applied through the Internet connection and realized with the help of Webinar technology. But before discussing the peculiarities of applying the kind of teaching practice mentioned above, we should previously indicate the reasons of choosing this particular way of Internet communication.

It is well-known that there is a great variety of different ways of teacherstudent interaction via the Internet which can be conditionally divided into two main categories: off-line and on-line communication. In our opinion, to the first group the following must be referred: communication with the help of electronic messages (e-mail) and communication through the Web-page (site) of a teacher, exchange of personal ideas at the forums, blogging. To the rapid ways of teacher-student on-line collaboration we refer: correspondence by means of ICQ or QIP clients, Skype (correspondence as well as visual and audio socializing is expected) and also teacherstudent interaction over the system of Webinar. According to the results of our previous analysis of the advantages of each type of Internet cooperation it is the last method which is the most effective way of sociocultural competence formation while teaching foreign language to part-time students of technical specialties. 
So, we should proceed to consider the Webinars as a fundamental base for forming the sociocultural competence of part-time students in higher technical institutions.

Methodology of the research. Webinar (on-line seminar) is known as a technology which specifies that interactive lessons are arranged in virtual classroom providing the appropriate functions and potential for distance learning of students. Virtual classroom is software that models the environment of real classroom in the Internet [2, p. 34-35]. Apart from this, we should point out that Webinar is not simply the classroom lesson arranged virtually but also the tool giving part-time student the opportunity to gain the skills of foreign communication in not previously planned real situations and what is the most important to widen his own knowledge about the country which language is being taught. Taking into the consideration the fact that our investigation was conducted according to the needs of part-time engineering students one should pay attention to the fact that Webinar learning helps to implement the exchange of sociocultural information by students of different faculties and specialties that do not know each other. This approach is practically impossible during classroom lessons.

First of all, we have determined that it promotes significantly the interest and cognitive activity of students, introduces them to a new environment of communication and also gives the opportunity to get the practice of communication in foreign language in unusual (not previously prepared) spontaneous situations.

Consequently, all above mentioned reasons prove that Webinar can actually be one of the leading means of forming the foreign sociocultural competence of non-linguistic part-time students. Given conclusion became the starting point of conducting the experiment with the second year part-time students of the Faculties of Welding, Physical Engineering and Chemical Technology. To reach our methodological goals we chose the consulting hours as a time of our experiment and a free platform Mikogo as its place. Taking into account that input capability of given platform has the limitation of ten people, by means of previous testing three best second year students from each faculty which took part in the further experiment were selected. During the classroom lessons the topic of the future seminar "World Famous Inventors and Inventions" was chosen. Students obtained the task to revise as much material as possible about inventions and inventors in the field of physics, chemistry and welding in order to have the possibility to exchange the relevant information. Before the seminar all participants received corresponding e-mail references to join the seminar at the definite time.

Results of the Research. During the seminar each student could lead the process so be in charge of the seminar. It is our firm belief that this approach encourages student's interest and motivation to participate in such kind of learning activity. Connection between the participants was supported by means of Internet after joining the page of interactive classroom (classroom of webinar). Previously prepared presentations, pictures, tables were transmitted on the screen; students asked thematic questions and got answers taking part in the discussion; participants could also work in groups. When the time of a given seminar expired (80 minutes), computer survey and testing according to the topic of a seminar was conducted that 
gave the opportunity to evaluate its results and efficiency by an estimated $87 \%$. After the results of the testing were processed the following was discovered: all the students widened their knowledge on technical topic and enriched their vocabulary exchanging the ideas and thoughts concerning the greatest scientists and their discoveries in the fields of physics, chemistry and welding; furthermore, students gained practical skills of communication in English language with new people in a new environment and opportunity to train rapid reaction to be able to form grammatically correct phrases asking and answering questions.

Conclusions. Thus, it may be stated that the issue under consideration is a topical problem which is connected not only to the specific features of part-time teaching but also to webinar as a new platform for teacher-student interaction during tutorial hours. The results of the preliminary study make it possible to conclude that English language tutorial hours should be divided as follows: $45 \%$ of the period could be devoted to the tutorial classroom training; $45 \%$ of time should be intended for English trainings via Internet; the quantity of hours dedicated to on-line conferences and seminars could average about $10 \%$. According to the classification of the interactive methods of teaching one of the most effective methods for teacher-student interaction via Internet is seminar which should be taken on the webinar platform. Thus, webinar appears to be effective tool of forming foreign sociocultural competence of part-time engineering students. However, we should also indicate that the results obtained are prior and cannot be accepted as the final statement because the number of participants was minimal. Consequently, as the prospects of our further research we consider the experiments with a bigger number of potential participants.

\section{ЛIТЕРАТУРА}

1. Гришкова Р. О. Формування іншомовної соціокультурної компетенції студентів нефілологічних спеціальностей [Текст] : монографія Р. О. Гришкова. - Миколаїв : Вид-во МДГУ ім. Петра Могили, 2007. - 424 с.

2. Морзе Н. В. Методичні особливості вебинарів, як інноваційної технології навчання [Текст] / Н. В. Морзе, О. В. Ігнатенко // Інформаційні технології в освіті: зб. наук. пр. - Херсон: ХДУ, 2010. - Вип. 5. - С. 31-39.

3. Полат Е. С. Современные педагогические и информационные технологии в системе образования [Текст] : учеб, пос / Е.С. Полат, М. Ю. Бухаркина. - М. : Издат. Центр «Академия», 2007. - 368 с.

4. Топалова В. М. Формування соціокультурної компетенції студентів технічного вузу (на матеріалі англійської мови) [Текст] : автореф. дис... канд. пед. наук: 13.00.02 / В. М. Топалова ; [Київський держ. лінгвістичний ун-т]. К., 1998. - $17 \mathrm{c}$.

\section{REFERECES}

1. Hryshkova, R.O. (2007). Formuvannia inshomovnoi sotsiokulturnoi kompetentsii studentiv nefilolohichnykh spetsialnostei [Formation of foreign language sociocultural competence of students of non-philological specialities]. Mykolaiv, Ukraine: MDHU im. Petra Mohyly Publ., 424. [in Ukrainian].

2. Morze, N.V. \& Ihnatenko, O.V. (2010). Metodychni osoblyvosti vebynariv, yak innovatsiinoi tekhnolohii navchannia [Methodological peculiarities of webinars as innovative learning technologies]. Information Technologies in Science, 5, 31-39. [in Ukrainian]. 
3. Polat, E.S., \& Buharkina, M.Yu. (2007). Sovremennye pedagogicheskie i informacionnye tehnologii $\mathrm{v}$ sisteme obrazovanija [Modern pedagogical and informational technologies in the system of education]. Moscow, Russia: Akademija Publ, 368. [in Russian]

4. Topalova, V. N. (1998). Formuvannia sotsiokulturnoi kompetentsii studentiv tekhnichnoho vuzu (na materiali anhliiskoi movy) [Formation of English language sociocultural competence of students in technical university]. Kyiv State Linguistic University, Kyiv, Ukraine, 17. [in Ukrainian]

Я. С. Грищенко， І. А. Сидоренко. Роль новітніх інтерактивних дистанційних технологій у формуванні іншомовної соціокультурної компетенції студентів заочників технічних спеціальностей ВНЗ.

Стаття присвячена визначенню ролі новітніх інтерактивних дистанційних технологій у формуванні іншомовної соціокультурної компетенції студентів заочної форми навчання вищих технічних навчальних закладів. На початку статті викладено кількісні показники часу, відведеного на самостійну роботу студентів, який припадає на консультації через мережу Інтернет, аудиторні консультації та on-line конференції й семінари. У статті наведено детальний огляд інтерактивних засобів навчання, які можуть використовуватися підчас дистанційного спілкування студентів та викладача у міжсесійний період. У роботі також здійснено аналіз засобів спілкування викладача зі студентами через мережу Інтернет, у рамках якого розглянуто два види спілкування - off-line та on-line. До першого виду віднесено спілкування за допомогою електронного листування, обмін поглядами на форумах, ведення блогів, спілкування через Web-copiнку (сайт) викладача, а до другого - листування за допомогою ICQ, Quip, Skype та спілкування через систему вебінара, поняття якого детально розглянуто у роботі. Практичну частину статті складають результати проведеного експерименту зі студентами зварювального, інженерно-фізичного та хіміко-технологічного факультетів на платформі Mikogo за темою "World Famous Inventors and Inventions". Наприкінці статті зроблено загальний висновок про те, що вебінар, дійсно, є ефективним засобом формування іншомовної соціокультурної компетенції студентів заочної форми навчання вищих технічних навчальних закладів. Перспективою подальших досліджень окреслено: проведення експериментів на більшому колі учасників та більш детальний розгляд можливостей використання платформ вебінарів у процесі навчання іноземної мови.

Ключові слова: іншомовна соціокультурна компетенція, дистанційне навчання, вебінар, інтерактивний метод, семінар.

Я. С. Грищенко, И. А. Сидоренко. Роль новейших интерактивных дистанционых технологий в формировании иноязычной социокультурной компетенции студентов-заочников технических специальностей ВУЗов.

Данная статья посвящена изучению роли интерактивных дистанционных технологий в формировании иноязычной социокультурной компетенции студентов технических специальностей заочного отделения ВУЗов. В начале статьи изложены количественные показатели времени, отведенного на самостоятельную работу студентов. В статье приведен детальный обзор интерактивных способов обучения, которые могут быть использованы во время дистанционного общения студентов и преподавателя в межсессионный период. В работе, также, осуществлен анализ способов общения преподавателя со студентами через Интернет, в рамках которого рассмотрены два вида общения - off-line и on-line. Практическую часть статьи составляют результаты проведенного эксперимента со студентами сварочного, инженерно-физического и химико-технологического факультетов на платформе Mikogo по теме "World Famous Inventors and Inventions". В результате проведенного эксперимента установлено, что эффективным способом формирования иноязычной социокультурной компетенции является вебинар.

Ключевые слова: иноязычная социокультурная компетенция, дистанционное обучение, вебинар, интерактивный метод, семинар. 